\title{
Implementasi Undang-Undang Keterbukaan Informasi Publik Dan Transparansi Pelayanan Publik Di Jawa Timur
}

\author{
Wahyu Saputra \\ Institut Agama Islam Negeri (IAIN) Ponorogo \\ Email : wahyouae@gmail.com
}

\begin{abstract}
One of the objectives of the Law on Public Information Openness (UU KIP) is to encourage the creation of transparency in public information services to the public. The goal is at the same time as an effort to realize the implementation of democratic governance and good governance. The purpose of this study was to analyze the implementation of the UU KIP in promoting transparency in public services in East Java. The research method used in this study is a normative-empirical research method. The data analysis method used is descriptive-analytical. The results of the study indicate that the implementation of the KIP Law in encouraging transparency in public services has not been able to be carried out optimally, as evidenced by the still many complaints and public information disputes that entered the East Java Information Commission.
\end{abstract}

\begin{abstract}
Abstrak
Salah satu tujuan ditetapkannya Undang-undang Keterbukaan Informasi Publik (UU KIP) adalah untuk mendorong terciptanya transparansi pelayanan informasi public pada masyarakat. Tujuan itu sekaligus sebagai upaya untuk mewujudkan pelaksanaan pemerintahan yang demokratis dan good governance. Tujuan penelitian ini adalah untuk menganalisis implementasi UU KIP dalam mendorong transparansi pelayanan public di Jawa Timur. Adapun metode penelitian yang digunakan dalam penelitian ini adalah metode penelitian normatif-empiris. Metode analisis data yang digunakan adalah metode analisis data deskriptif-analitis. Hasil penelitian menunjukkan bahwa implementasi UU KIP dalam mendorong transparansi pelayanan public belum bisa dijalankan secara maksimal, dibuktikan dengan masih banyaknya laporan pengaduan dan sengketa informasi public yang masuk di Komisi Informasi Jawa Timur.
\end{abstract}

Keywords : Informasi Publik, Badan Publik, Transparansi

\section{PENDAHULUAN}

Banyak akademisi yang mengatakan bahwa gerakan reformasi tahun 1998 dan jatuhnya Soeharto merupakan awal wajah baru demokrasi dalam sistem pemerintahan di Indonesia, walaupun tidak bisa dipungkiri sejak Indonesia merdeka nilai-nilai demokrasi sudah mendasari sistem pemerintahan Negara ini.

Menurut Mahdi $^{1}$ setidaknya ada 3 wajah demokrasi dalam sistem pemerintahan di Indonesia sebelum reformasi yaitu; demokrasi parlementer ${ }^{2}$,

\footnotetext{
${ }^{1}$ Imam Mahdi, 2011, Hukum Tatanegara Indonesia, Penerbit Teras, Yogyakarta, hlm. 209.

${ }^{2}$ Pada umumnya system parlementer ketika itu disamakan dengan demokrasi liberal, meskipun pada dasarnya baik system parlementer dan system presidensial sama-sama didasarkan pada asaz demokrasi dengan trias politika. Lihat lebih lanjut dalam buku, Mahfud MD, Politik Hukum di Indonesia, (Jakarta: PT. RajaGrafindo Persada, 2012), hlm. 35.
} 
demokrasi terpimpin ${ }^{3}$, dan demokrasi Pancasila ${ }^{4}$. Demokrasi pertama-tama merupakan gagasan yang mengandaikan bahwa kekuasaan itu adalah dari, oleh, dan untuk rakyat. Artinya, kekuasaan itu pada pokoknya diakui berasal dari rakyat dan karena itu rakyatlah yang sebenarnya menentukan dan memberi arah serta menyelenggarakan kehidupan kenegaraan. Oleh sebab itu konsep Negara yang baik idealnya diselenggarakan bersama-sama dengan rakyat dalam arti dengan melibatkan masyarakat seluas-luasnya. ${ }^{5}$

Komitmen untuk menjalankan sistem demokrasi yang baik harus mengedepankan syarat-syarat dalam sistem demokrasi. Menurut Lyman Tower Sargent seperti dikutip oleh R. Muhamad Mihardi, syarat demokrasi sebagai berikut;

(1) adanya keterlibatan rakyat dalam pengambilan keputusan, (2) adanya persamaan hak diantara warga Negara, (3) adanya kebebasan dan kemerdekaan yang diberikan atau dipertahankan serta dimiliki oleh warga Negara, (4) adanya sistem perwakilan yang efektif, dan (5) adanya sistem pemerintahan yang menjamin dihormatinya prinsip ketentuan mayoritas. ${ }^{6}$

Syarat-syarat demokrasi di atas sebagai gambaran umum yang harus dijalankan dalam sistem demokrasi, sedangkan ciri dari sistem demokrasi modern selalu menekankan prinsip adanya Hak Asasi Manusia dan juga partisipasi rakyat dalam menjalankan sistem pemerintahan. Ini dikarenakan jaminan, penghargaan, dan persamaan Hak Asasi Manusia.

Hak Asasi Manusia bermula dari sebuah gagasan bahwa manusia tidak boleh diperlakukan semena-mena oleh penguasa (kekuasaan). Manusia memiliki hak alamiah yang melekat begitu saja pada manusia. Hak tersebut ada secara

3 Demokrasi terpimpin merupakan penolakan terhadap system yang berlaku sebelumnya (demokrasi parlementer), ketika politik sangat ditentukan oleh politik partai-partai melalui system free fight. Proses pengambilan keputusan dalam demokrasi terpimpin didasarkan pada musyawarah dan mufakat serta semangat gotong royong dibawah kepemimpinan Presiden Soekarno yang kemudian menampilkan Soekarno sebagai penguasa yang otoriter. Ibid., hlm. 129 .

${ }^{4}$ Pada masa ini system pemerintahan menampilkan konfigurasi politik yang otoriter birokratis yang diperlukan untuk mengamankan jalannya pembangunan. Ibid., hlm. 195.

${ }_{5}^{5}$ Jimly Asshiddiqie, Hukum Tata Negara dan Pilar-pilar Demokrasi, Serpihan Pemikiran Hukum, Media, dan HAM, (Jakarta: Konstitusi Pers, 2005), hlm. 241.

${ }^{6}$ R. Muhammad Mihardi, Kebebasan Informasi Publik Versus Rahasia Negara, (Bogor: Penerbit Galia, 2011), hlm. 34. 
kodrati yang merupakan pemberian Tuhan. Manusia memiliki karena kemanusiaannya, bukan karena etnis, ras, jenis kelamin, apalagi agama, hak alamiah melekat pada diri manusia sebagai individu. Negara, komunitas atau kelompok tidak dapat membatasi hak-hak itu tanpa persetujuan bebas dari individu.

Doktrin tentang Hak Asasi Manusia sekarang ini sudah diterima secara universal sebagai a moral, political, legal framework and as a guideline dalam membangun dunia yang lebih damai dan bebas dari ketakutan dan penindasan serta perlakuan yang tidak adil. Dalam paham negara hukum, jaminan HAM sebagai ciri yang mutlak harus ada di setiap negara. Jaminan-jaminan HAM itu juga diharuskan dengan tegas tercantum dalam Undang-undang Dasar atau konstitusi tertulis negara demokrasi konstitusional (constitutional democracy). ${ }^{7}$

Sejalan dengan perkembangan HAM di Indonesia, ketentuan-ketentuan konstitusi dan perundang-undangan telah melembagakan nilai-nilai jaminan HAM, baik UUD 1945 pra maupun pasca perubahan. Dalam UUD 1945 amandemen ke empat, HAM diatur dalam BAB XA mulai dari pasal 28A sempai pasal 28J. Termasuk di dalamnya mengatur tentang hak sipil dan politik yang diantaranya adalah hak kebebasan memperoleh informasi.

Dalam demokrasi mensyaratkan adanya kebebasan dan keterbukaan dalam memperoleh informasi publik. Keterbukaan atau transparansi dalam perkembangannya menjadi salah satu prinsip atau pilar Negara demokrasi demi terwujudnya control social. Control social tersebut bisa terlaksana jika masyarakat diberikan akses yang terbuka untuk memperoleh informasi berkaitan dengan pelaksanaan kebijakan publik.

Informasi merupakan kebutuhan pokok setiap orang, baik dalam rangka mengembangkan kualitas pribadi maupun dalam rangka menjalani kehidupan sosialnya. Tidak salah jika kebebasan memperoleh informasi publik merupakan bagian dari HAM yang dijamin dalam Universal Declaration of Human Rights (DUHAM) pada Pasal 19, sebagai berikut: "Everyone has the right to freedom of

\footnotetext{
${ }^{7}$ Jimly Asshiddiqie, Pengantar Ilmu Hukum Tata Negara Jilid 2, (Jakarta: Sekretariat Jenderal dan Kepaniteraan Mahkamah Konsititusi RI, 2006), hlm. 85.
} 
opinion and expression; this right includes freedom to hold opinions without interference and to seek, receive and impart information and ideas through any media and regardless of frontiers".

Sejalan dengan itu, akses terhadap informasi merupakan bagian dari hak asasi manusia yang dijamin dan dilindungi konstitusi. Pada perubahan kedua UUD 1945 Pasal 28F dinyatakan bahwa: Setiap orang berhak untuk berkomunikasi dan memperoleh informasi untuk mengembangkan pribadi dan lingkungan sosialnya, serta berhak untuk mencari, memiliki, menyimpan, mengolah, dan menyampaikan informasi dengan menggunakan segala jenis saluran yang tersedia". ${ }^{8}$

Setelah reformasi tahun 1998 semangat untuk memperjuangkan hak untuk memperoleh informasi publik terus disuarakan. Banyak undang-undang yang dibuat pasca reformasi yang memasukkan hak memperoleh informasi publik bagi masyarakat ke dalam beberapa Pasalnya. Diantaranya adalah UU No. 39 Tahun 1999 tentang HAM dalam Pasal 14 dan 90, UU No. 40 Tahun 1999 tentang Pers dalam Pasal 4 dan 17, UU No. 8 Tahun 1999 tentang Perlindungan Konsumen dalam Pasal 3, 4, dan 7. UU No. 28 Tahun 1999 Tentang Penyelenggaraan Negara yang bersih dan bebas korupsi, kolusi, dan nepotisme dalam Pasal 3, 5, dan 9, UU No. 31 Tahun 1999 Tentang Pemberantasan tindak pidana korupsi Pasal 41, dan masih banyak lagi.

Dalam perkembangan selanjutnya pengaturan tentang kebebasan dalam memperoleh informasi publik diatur tersendiri dalam Undang-undang No. 14 Tahun 2008 tentang Keterbukaan Informasi Publik (selanjutnya disingkat dengan UU KIP) yang disahkan pada tanggal 30 April 2008. Pada awalnya Undangundang tersebut merupakan gagasan dari sekelompok LSM yang tergabung dalam Koalisi untuk Kebebasan Memperoleh Informasi Publik (KMIP). Pada tahun 2000 KMIP yang dimotori oleh Komisi Hukum Nasional dan sejumlah LSM terkemuka seperti, Aliansi Jurnalistik Indonesia (AJI), Indonesian Center for Environmental Law (ICEL), Konsorsium Reformasi Hukum Nasional (KRHN), Komite Peduli

\footnotetext{
${ }^{8}$ Henry Subagyo. Dkk, Anotasi Undang-Undang Nomor 14 Tahun 2008 Tentang Keterbukaan Informasi Publik, (Jakarta: Komisi Informasi Pusat RI, 2009), hlm, 11.
} 
Otonomi Daerah (KPOD), dan sebagainya. Kemudian melalui proses panjang, loby dan negosiasi, pada maret 2002, DPR mengadopsi draf RUU KMIP. ${ }^{9}$

Keberadaan Undang-Undang No. 14 Tahun 2008 tentang Keterbukaan Informasi Publik memberikan pencerahan dalam pelaksanaan penyelenggaraan Negara atau pemerintahan. Pelaksanaan keterbukaan informasi publik dalam penyelenggaraan Negara atau pemerintahan merupakan perwujudan tata pemerintahan yang baik (Good Governance), dan jaminan kepastian hukum terhadap hak masyarakat untuk mendapatkan informasi yang dibutuhkan serta untuk turut serta dalam mengontrol penyelenggaraan Negara atau pemerintahan.

UU KIP memberikan jaminan kepada setiap warga Negara untuk memperoleh informasi yang dikuasai oleh Badan Publik. UU KIP memberikan acuan yang sangat jelas kepada warga Negara tentang tata cara memperoleh informasi dari badan publik. UU KIP juga mengatur tentang apa yang harus dilakukan oleh warga Negara (pemohon informasi publik) jika niatnya untuk memperoleh informasi dari badan publik dihambat oleh pejabat di dalam publik tersebut. Penyelesaian sengketa permintaan informasi tersebut akan diselesaikan oleh Komisi Informasi. ${ }^{10}$

Dengan berlakunya UU KIP masyarakat bisa ikut serta dan berpartisipasi dalam menjalankan sistem pemerintahan. Partisipasi masyarakat tersebut bisa diwujudkan dengan keikutsertaan dalam melakukan control dan evaluasi kebijakan publik yang akan ataupun telah dilaksanakan oleh lembaga publik. Keikutsertaan dalam evaluasi (participation in evaluation) merupakan keikutsertaan dalam mengawasi dan menilai pelaksanaan hasil-hasil perencanaan. Masyarakat dapat memberikan saran dan kritik terhadap pelaksanaan pemerintahan agar sesuai dengan apa yang telah direncanakan dan mencapai hasil yang telah ditetapkan. Menurut Suwignjo seperti dikutip oleh Mulyadi ${ }^{11}$

\footnotetext{
${ }^{9}$ R. Muhammad Mihardi, Op.Cit, hlm. 5.

10 Agus Sudibyo, dkk, Panduan Sederhana Penerapan UU Keterbukaan Informasi Publik, Yayasan Yet, Jakarta, hlm. VI.

${ }^{11}$ Muhammad Mulyadi, Partisipasi Masyarakat dalam Pembagunan Masyarakat Desa, (Jakarta: Nadi Pustaka, 2009), hlm. 45.
} 
"partisipasi dalam evaluasi bertujuan untuk menjamin agar semua pekerjaan yang sedang dilakukan berjalan sesuai rencana yang telah ditentukan sebelumnya”.

Badan publik mempunyai kewajiban untuk memberikan serta mensosialisasikan informasi publik yang berhak diketahui oleh masyarakat, hal tersebut diatur dalam UU KIP Pasal 7. Penjelasan tentang Badan Publik sendiri diatur dalam Pasal 1 ayat 3 UU KIP, yaitu :

"Badan Publik adalah lembaga eksekutif, legislatif, yudikatif, dan badan lain yang fungsi dan tugas pokoknya berkaitan dengan penyelenggaraan negara, yang sebagian atau seluruh dananya bersumber dari Anggaran Pendapatan dan Belanja Negara dan/atau Anggaran Pendapatan dan Belanja Daerah, atau organisasi non-pemerintah sepanjang sebagian atau seluruh dananya bersumber dari Anggaran Pendapatan dan Belanja Negara dan/atau Anggaran Pendapatan dan Belanja Daerah, sumbangan masyarakat, dan/atau luar negeri." 12

Dalam memberikan informasi kepada masyarakat tidak semua informasi boleh diberikan kepada masyarakat. Ada beberapa informasi yang bersifat rahasia dan dikecualikan yang tidak boleh disebarluaskan dan diberikan kepada masyarakat seperti yang diatur dalam Pasal 17 UU KIP.

Permintaan informasi publik oleh masyarakat kepada badan publik ada kemungkinan tidak dilayani atau tidak diberikan oleh badan publik yang bersangkutan. Kemungkinan tersebut yang akan menimbulkan konflik ${ }^{13}$ atau sengketa informasi. Dalam UU KIP juga mengatur tentang bagaimana menyelesaikan sengketa yang terjadi antara masyarakat dengan badan publik.

\section{Badan Publik dan Tanggungjawab Pelayanan Publik}

Dalam UU KIP dijelaskan definisi tentang Badan Publik adalah lembaga eksekutif, legislatif, yudikatif, dan badan lain yang fungsi dan tugas pokoknya berkaitan dengan penyelenggaraan negara, yang sebagian atau seluruh dananya

\footnotetext{
${ }^{12}$ Pasal 1 ayat 3 Undang-undang No. 14 Tahun 2008 tentang Keterbukaan Informasi Publik, Lembaran Negara Republik Indonesia Tahun 2008 Nomor 61.

${ }^{13}$ Konflik merupakan bagian dari proses sengketa mengingat proses konflik mencangkup tahapan potensi konflik namun penggunaan istilah sengketa sering dipersamakan dengan konflik yaitu suatu kondisi yang ditimbulkan oleh dua orang atau lebih yang dicirikan oleh beberapa tanda pertentangan secara terang-terangan, baik disebabkan oleh rasa tidak puas, perbedaan pendapat, dan atau diperlakukan secara tidak adil. Lihat Selengkapnya dalam, Ade Saptomo, Hukum Dan Kearifan Lokal; Revitalisasi Hukum Adat Nusantara, (Jakarta: PT. Gramedia Widiasarana Indonesia, 2010), hal. 29.
} 
bersumber dari Anggaran Pendapatan dan Belanja Negara dan/atau Anggaran Pendapatan dan Belanja Daerah, atau organisasi nonpemerintah sepanjang sebagian atau seluruh dananya bersumber dari Anggaran Pendapatan dan Belanja Negara dan/atau Anggaran Pendapatan dan Belanja Daerah, sumbangan masyarakat, dan/atau luar negeri. ${ }^{14}$

Pendefinisian badan publik dalam perundang-undangan di Indonesia baru kali pertama dilakukan dalam UU KIP. Dalam UU KIP Badan Publik dibagi menjadi tiga bagian, yaitu:

a. Badan publik yang secara konvensional selama ini diartikan sebagai penyelenggara pemerintahan, yaitu lembaga eksekutif, legislatif, yudikatif dan badan lain yang fungsi dan tugas pokoknya berkaitan dengan penyelenggaraan Negara yang mana sebagian atau seluruh dananya bersumber dari APBN/D;

b. Organisasi non-pemerintah sepanjang sebagian atau seluruh dananya bersumber dari APBN/D, sumbangan masyarakat dan/atau sumbangan luar negeri. ${ }^{15}$

c. Badan lain yang fungsi dan tugas pokoknya berkaitan dengan penyelenggaraan negara, yaitu: partai politik, perguruan tinggi, perpustakaan nasional, arsip nasional, kepolisian, BLU Transjakarta, dll. ${ }^{16}$

Dari kriteria tersebut dapat dikatakan bahwa tidak ada lembaga pemerintah maupun non pemerintah seperti yang dimaksud dalam UU KIP terbebas dari kewajiban memberikan informasi kepada masyarakat.

Pakar hukum Dian Puji Simatupang dari Universitas Indonesia mengatakan, dalam merumuskan pengertian badan publik perlu ditekankan tentang kriteria publik itu sendiri. Menurutnya, publik dalam UU KIP diartikan sebagai kepentingan publik. UU KIP secara sistematis juga merumuskan bahwa kepentingan publik tersebut merupakan kepentingan umum yang dilaksanakan

\footnotetext{
${ }^{14}$ UU KIP, Pasal 1 (3).

${ }^{15}$ Henry Subagiyo dkk, Op.cit., hlm. 37.

${ }^{16}$ Dhoho A. Sastro, dkk, Mengenal Undang-undang Keterbukaan Informasi Publik, (Jakarta: LBH Masyarakat dan TIFA, 2010), hlm 18.
} 
oleh alat-alat negara, baik yang wewenangnya diperoleh secara atributif, delegatif, mandat atau adanya konsesi. Alat-alat Negara demikian juga disebut sebagai badan publik. ${ }^{17}$

Harus pula diperhatikan, bahwa dalam ilmu hukum dikenal dua jenis badan hukum: badan hukum publik dan badan hukum privat. Perbedaan keduanya adalah dalam hal kewenangan mengeluarkan kebijakan. Badan hukum publik memiliki kewenangan mengeluarkan kebijakan publik yang mengikat umum, sedangkan badan hukum privat tidak memiliki kewenangan tersebut. Badan hukum publik, misalnya badan-badan hukum Negara seperti departemen dan lembaga non departemen yang menjadi bagian dari pelaksanaan tugas pemerintahan dan penyelenggaraan pemerintahan.

Salah satu tanggungjawab pelaksanaan tugas pemerintahan yang harus dijalankan oleh badan public adalah melakukan pelayanan public. Tugas ini melekat secara wajib pada setiap badan public karena pada esensinya setiap badan public adalah bagian dari lembaga pemerintahan yang bertanggungjawab dan berfungsi dalam melakukan pelayanan kepada masyarakat.

Pelayanan publik merupakan elemen yang sangat penting dalam penyelenggaraan pemerintahan. Pelayanan publik secara sederhana dipahami oleh berbagai pihak sebagai pelayanan yang diselenggarakan oleh pemerintah. Menurut UU No. 25 Tahun 2009 Pasal 1 dijelaskan; "Pelayanan publik adalah kegiatan atau rangkaian kegiatan dalam rangka pemenuhan kebutuhan pelayanan sesuai dengan peraturan perundang-undangan bagi setiap warga negara dan penduduk atas barang, jasa, dan/atau pelayanan administrasi yang disediakan oleh penyelenggara pelayanan publik."18 Selain itu dalam banyak literature menyatakan "what government does is public service". ${ }^{19}$ Pendapat tersebut menunjukkan bahwa pada dasarnya pemerintah memang memiliki peran yang sangat penting dalam penyelenggaraan pelayanan publik.

\footnotetext{
${ }^{17}$ Henry Subagiyo, Op.cit., hlm. 38.

${ }^{18}$ Undang-undang No. 25 Tahun 2009 Tentang Pelayanan Publik pasal 1.

${ }^{19}$ Dwiyanto, Agus, Manajemen Pelayan Publik: Peduli, Inklusif, dan Kolaboratif, (Yogyakarta: Universitas Gajah Mada Press, 2015). Hal 14.
} 
Definisi pelayanan publik menurut Kepmen PAN Nomor 25 Tahun 2004 adalah segala kegiatan pelayanan yang dilaksanakan oleh penyelenggara pelayanan publik sebagai upaya pemenuhan kebutuhan penerima layanan, maupun dalam rangka pelaksanaan ketentuan peraturan perundang-undangan. ${ }^{20}$ Sedangkan Kepmen PAN Nomor 58 Tahun 2002 mengelompokkan tiga pelayanan dari instansi serta BUMN/BUMD. Pengelompokkan jenis pelayanan tersebut didasarkan pada ciri- ciri dan sifat kegiatan serta produk pelayanan yang dihasilkan, yaitu (1) pelayanan administratif, (2) pelayanan barang, (3) pelayanan jasa. $^{21}$

Mengacu pada pendapat di atas, menjadikan bukti bahwa pelayanan publik merupakan bentuk layanan yang diberikan pemerintah untuk memenuhi kebutuhan hidup masyarakatnya. Pelayanan publik juga harus mengacu dan didukung oleh undang-undang atau regulasi yang berlaku sehingga dapat menjadi acuan dalam penyelenggarannya. Selain pihak dari pemerintah yang menjadi penyelenggara pelayanan publik, dimungkinkan pula pelayanan publik diselenggarakan oleh pihak non pemerintah, seperti swasta atau masyarakat. Namun hal tersebut tidak seakan-akan membantah bahwa peran pemerintah begitu penting dalam penyelenggaraan pelayanan publik bagi masyarakatnya.

Pelayanan oleh pemerintah (government service) dapat dimaknai sebagai "the delivery of a service by a government agency using its own employees" 22 dengan kata lain bahwa pemberian pelayanan kepada masyarakat/warga negara yang dilakukan oleh agen pemerintah melalui pegawainya. Penyediaan pelayanan publik secara langsung oleh pemerintah dilakukan lewat apa yang disebut sebagai sektor publik (public sector), yaitu badan-badan pemerintah, sekolah milik pemerintah, kantor pos, perusahaan listrik pemerintah, rumah sakit milik pemerintah, dan seterusnya. ${ }^{23}$ Penyelenggaraan yang dilakukan oleh pemerintah dilaksanakan demi tujuan agar tidak tejadi penyalahgunaan. Pemerintah sebagai

\footnotetext{
${ }^{20}$ Keputusan Menteri Pendayagunaan Aparatur Negara No. 25 Tahun 2004.

${ }^{21}$ Keputusan Menteri Pendayagunaan Aparatur Negara No. 58 Tahun 2002.

22 Savas, E.S, "Privatization: The Key to Better Government", (New Jersey: Chatam House Publisher, 1987), Hal 62.

${ }^{23}$ Putra, Fadhilla, New Public Governance. (Malang: UB Press, 2012), Hal. 62
} 
penyedia harus bersikap secara professional dalam menjalankan fungsinya sebagai penyedia pelayanan publik.

Dalam memberikan pelayanan kepada masyarakat, pemerintah diharapkan selalu dapat melakukannya secara maksimal, dan pelayanan publik yang demikian itu umumnya iistilahkan sebagai pelayanan prima. Dalam banyak pustaka, pelayanan prima digambarkan sebagai pelayanan yang prosedurnya tidak berbelitbelit, dengan biaya yang murah serta waktu yang singkat. Pelayanan public yang baik juga bertujuan untuk mendorong pelaksanaan dan budaya system birokrasi badan public yang transparan dan akuntable.

\section{Transparansi Informasi dan Pelayanan Publik}

Dalam Negara demokrasi peran serta masyarakat untuk ikut serta mengawal jalannya pemerintahan merupakan cirri utama dalam Negara demokrasi. Peran serta tersebut sebagai wujud implementasi dari prinsip kedaulatan rakyat, dimana kekuasaan tertinggi dalam Negara demokrasi berada di tangan rakyat. Bentuk peran serta dalam mengawal jalannya permerintahan kemudian dilaksanakan dengan salah satunya adalah melakukan control dan pengawasan terhadap kinerja badan public.

Partisipasi masyarakat baik secara langsung ataupun tidak langsung dalam melakukan control terhadap jalannya pemerintahan pada hakikatnya sebagai salah satu upaya agar pemerintahan bias berjalan dengan baik sesuai dengan prinsip good governance. Good governance sendiri digambarkan sebagai jalannya pemerintahan yang akuntable, transparan, professional, responsive, bebas dari KKN dalam rangkan untuk mencapai tujuan Negara.

Atas dasar konsep di atas, masyarakat kemudian diberikan hak atas informasi kebijakan public yang dikelola oleh badan publik. Hak atas informasi tersebut sebagai wujud dari partisipasi masyarakat untuk mengetahui dan memberikan kritik serta saran kepada badan public jika ada kebijakan public yang dinilai tidak sesuai dengan kepentingan masyarakat umum. Di sisi lain, akses informasi yang diberikan kepada masyarakat memberikan kesempatan kepada masyarakat untuk melakukan pengawasan kepada pemerintah agar tidak 
sewenang-wenang dan menyalahgunakan kekuasaan untuk kepentingan pribadi maupun golongan.

Hak atas informasi publik telah diakui lewat berbagai ketentuan di instrumen pokok HAM Internasional sebagai salah satu bagian dari katalog hak asasi yang penting. Secara literal "hak untuk mencari, menerima, dan menyampaikan infromasi dan pemikiran"24 tercantum dalam Pasal 19 baik di Deklarsi Universal Hak Asasi Manusia (DUHAM) maupun di Kovenan Hak-hak Sipil dan Politik (ICCPR). Keduanya merupakan pilar utama dari instrumen induk HAM internasional (international bill of human rights), selain Kovenan Hak-hak Ekonomi, Sosial, dan Budaya (ICESCR). Namun, elaborasi sebagai hak asasi yang otonom agak minim. Hak atas informasi publik ini selalu dikaitkan dan diintegrasikan dengan hak untuk bebas berekspresi dan menyatakan pedapat yang jauh lebih populer di mata para ahli dan praktisi HAM. ${ }^{25}$

Jaminan hukum tentang Hak memperoleh informasi dalam sistem hukum di Indonesia sendiri diatur dalam Undang-undang Dasar 1945 Pasal 28F, bahwa "Setiap orang berhak untuk berkomunikasi dan memperoleh informasi untuk mengembangkan pribadi dan lingkungan sosialnya, serta berhak untuk mencari, memperoleh, memiliki, menyimpan, mengolah, dan menyampaikan informasi dengan menggunakan segala jenis saluran yang tersedia". ${ }^{26}$ Jaminan hukum tersebut didasarkan atas peraturan hukum internasional salah satunya adalah DUHAM karena Indonesia sebagai Negara yang telah meratifikasi peraturan tersebut, oleh sebab itu amanat dalam peraturan tersebut wajib dimasukkan dalam sistem hukum di Indonesia.

\footnotetext{
${ }^{24}$ Rumusan "hak untuk mencari, menerima, dan menyampaikan infromasi dan pemikiran" ini serupa dengan ketentuan yang ada pada Europan Convention on Human Rights (Pasal 10); American Convention on Human Rights (pasal 13); dan sedikit berbeda pada African Charter on Human and Peoples' Rights (Pasal 9 yang menyatakan "hak untuk menerima informasi").

${ }^{25}$ Sebenarnya hak atas informasi publik telah dikenal dan diakui sebagai hak asasi secara global lewat Resolusi Majelis Umum PBB pada tahun 1946. Lalu masuk di dalam Deklarasi Universal Hak Asasi Manusia (DUHAM) 1948. Dan kemudian diakui oleh instrumen HAM Internasional yang memilik kekuatan hukum mengikat, yaitu Kovenan Hak-Hak Sipil dan Politik (International Covenant on Civil and Political Rights) pada 1966. Lihat selengkapnya dalam, Tim Penyusun Kontras dan TIFA, Panduan Mengenal Hak atas Informasi Publik dan Pemolisian, (Jakarta: Kontras \& TIFA, 2011), hlm. 15.

${ }^{26}$ UUD 1945, Pasal 28F.
} 
Dalam perkembangannya, peraturan mengenai hak memperoleh informasi diatur secara otonom dalam berbagai peraturan perundang-undangan, salah satunya secara khusus dalam UU KIP Pasal 3 (a) dan 4 yang menyebutkan bahwa undang-undang tersebut "Menjamin hak warga negara untuk mengetahui rencana pembuatan kebijakan publik, program kebijakan publik, dan proses pengambilan keputusan publik, serta alasan pengambilan suatu keputusan publik; ${ }^{27}$. Selebihnya dalam Pasal 4 dijelaskan:

a. Setiap Orang berhak memperoleh Informasi Publik sesuai dengan ketentuan Undang-Undang ini.

b. Setiap Orang berhak:

1) Melihat dan mengetahui Informasi Publik;

2) Menghadiri pertemuan publik yang terbuka untuk umum untuk memperoleh Informasi Publik;

3) Mendapatkan salinan Informasi Publik melalui permohonan sesuai dengan Undang-Undang ini;

4) Menyebarluaskan Informasi Publik sesuai dengan peraturan perundang-undangan.

c. Setiap Pemohon Informasi Publik berhak mengajukan permintaan Informasi Publik disertai alasan permintaan tersebut.

d. Setiap Pemohon Informasi Publik berhak mengajukan gugatan ke pengadilan apabila dalam memperoleh Informasi Publik mendapat hambatan atau kegagalan sesuai dengan ketentuan Undang-Undang ini. $^{28}$

Era keterbukaan yang mengiringi Reformasi 1998 semakin menimbulkan kesadaran akan terbukanya akses informasi dari berbagai kalangan. Secara khusus, keterbukaan akses menuju informasi publik dibutuhkan oleh mereka yang berkecimpung dalam bidang lingkungan, gerakan anti korupsi, hak asasi manusia, dan pers yang sering mengalami kesulitan dalam mengakses berbagai informasi dari lembaga pemerintahan, dengan dalih rahasia negara. Meski demikian, hak untuk memperoleh informasi publik telah diatur dalam berbagai peraturan perundang-undangan yang bisa menjamin hak masyarakat untuk memperoleh informasi sebagai upaya untuk ikut serta dalam merumuskan kebijakan publik dan melakukan kontrol terhadap badan publik atau birokrasi pemerintahan.

\footnotetext{
${ }^{27}$ UU KIP, Pasal 3 (a).

${ }^{28}$ Ibid., Pasal 4.
} 
Keterbukaan badan public dalam memberikan informasi kepada masyarakat merupakan tanggungjawab yang wajib dijalankan sesuai dengan amanat UU KIP. Salah satu dari tujuan UU KIP adalah untuk mewujudkan sistem yang transparan sebagai wujud pemerintahan yang baik juga. Pelaksanaan keterbukaan informasi publik dalam penyelenggaraan negara atau pemerintahan merupakan perwujudan tata pemerintahan yang baik (Good Governance), dan jaminan kepastian hukum terhadap hak masyarakat untuk mendapatkan informasi yang dibutuhkan serta untuk turut serta dalam mengontrol penyelenggaraan negara atau pemerintahan. Untuk mewujudkan tujuan tersebut, maka harus didukung dengan komitmen semua elemen pemerintahan dalam menjalankan UU KIP. Mewujudkan penyelenggaraan negara yang baik erat kaitannya dengan pelayanan publik. Secara korelasi, jika pelayanan publik itu baik, maka penyelenggaran negara juga bisa berjalan dengan baik. Sejalan dengan itu, jika pelayanan publik baik masyarakat dapat ikut serta dalam melakukan control terhadap pemerintah.

\section{Problematika Budaya Hukum Badan Publik di Jawa Timur}

Pada dasarnya substansi pelayanan publik selalu dikaitkan dengan suatu kegiatan yang dilakukan oleh seseorang atau kelompok orang atau instansi tertentu untuk memberikan bantuan dan kemudahan kepada masyarakat dalam rangka mencapai tujuan tertentu. Pelayanan kepada masyarakat dapat dilakukan oleh pemerintah, maupun non pemerintah. Organisasi birokrasi pemerintahan ${ }^{29}$ merupakan organisasi garis terdepan (street level bureaucracy) yang memberikan

\footnotetext{
${ }^{29}$ Birokrasi pemerintah seringkali diartikan sebagai officialdom atau kerajaan pejabat. Suatu kerajaan yang raja-rajanya adalah para pejabat dari suatu bentuk organisasi yang digolongkan modern. Di dalamnya terdapat tanda-tanda bahwa seseorang mempunyai yurisdiksi yang jelas dan pasti, mereka berada dalam area ofisial yang yurisdiktif. Di dalam yurisdiksi tersebut seseorang mempunyai tugas dan tanggung jawab resmi (official duties) yang memperjelas batas-batas kewenangan pekerjaannya. Mereka bekerja dalam tatanan pola hierarki sebagai perwujudan dari tingkatan otoritas dan kekuasaannya. Mereka memperoleh gaji berdasarkan keahlian dan kompetensinya. Selain itu dalam kerajaan pejabat tersebut, proses komunikasinya didasarkan pada dokumen tertulis (the jiles). Itulah kerajaan birokrasi yang rajanya para pejabat. Yurialis, 2012, Budaya Birokrasi Pemerintahan, Jurnal Sosial Budaya Vol. 9 No. 1 Januari-Juli 2012, hlm. 90.
} 
pelayanan kepada masyarakat. Budaya Birokrasi yang baik di pemerintahan menjadi penting, guna memberikan pelayanan jasa yang prima kepada publik (masyarakat). Pelayanan publik sebagai suatu proses kinerja organisasi (birokrasi), keterikatan dan pengaruh budaya organisasi sangatlah kuat. Dengan kata lain, idealnya apapun kegiatan yang dilakukan oleh aparat pelayanan publik haruslah berpedoman pada rambu-rambu aturan normatif yang telah ditentukan oleh organisasi publik sebagai perwujudan dari budaya organisasi publik. Dalam konteks itu, budaya yang terbangung dalam sistem birokrasi merupakan suatu cerminan dari ketaatan unsur-unsur di dalamnya dalam menjalankan sistem pemerintahan yang sesuai dengan tata aturan hukum.

Idealnya proses pelayanan publik memang harus dijalankan sesuai prinsip di atas, sekaligus ini menjadi sebuah upaya untuk menciptakan sistem birokrasi pemerintahan yang baik, namun pada kenyataannya, sekarang masih banyak birokrasi di Indonesia yang belum mampu menjalankan prinsip tersebut. Masih banyak birokrasi di Indonesia yang tidak memberikan pelayanan yang baik bagi masyarakat. Akses birokrasinya pun tertutup belum secara transparan memberikan informasi-informasi yang dibutuhkan oleh masyarakat. Kultur birokrasi pemerintahan yang seharusnya lebih menekankan pada pelayanan masyarakat ternyata tidak dapat dilakukan secara efektif oleh birokrasi di Indonesia. Secara struktural, kondisi tersebut merupakan implikasi dari sistem politik Orde Baru yang telah menempatkan birokrasi lebih sebagai instrumen politik kekuasaan dari pada sebagai agen pelayanan publik, sedangkan secara kultural, kondisi tersebut lebih disebabkan akar sejarah kultur feodalistik birokrasi.

Selain masalah di atas, sistem dan budaya birokrasi pemerintahan yang tidak terbuka tentunya akan sulit untuk dikontrol oleh masyarakat, sehingga kondisi tersebut memberikan satu peluang bagi aparatur pemerintahan untuk melakukan tindakan yang melanggar hukum dengan mensalahgunakan wewenang dan kekuasaannya, misalnya melakukan tindakan korupsi, dan sebagainya. Problem tersebut bukan suatu analisis kosong semata, akan tetapi banyaknya kasus-kasus korupsi oleh aparatur Negara yang saat ini terjadi merupakan salah satu akibat dari budaya dan sistem birokrasi yang tidak transparan juga. Hal 
tersebut menjadi sebuah tantangan besar pemerintahan untuk mencipatakan suatu sistem dan budaya birokrasi pemerintahan yang transparan agar akses control dari masyarakat kepada pemerintahan bisa dilakukan secara maksimal.

\section{Implementasi UU KIP pada Badan Publik di Jawa Timur}

Kondisi yang dipaparkan di atas menjadi sebuah tantangan besar yang harus dihadapi dalam implementasi UU KIP. Bagaimana tidak, bahwa sistem birokrasi yang kurang transparan tentunya akan mempersulit akses informasi oleh masyarakat yang sebenarnya dijamin oleh UU KIP. Dampak dari kondisi tersebut akhirnya banyak menimbulkan sengketa antara masyarakat dengan badan publik akibat tidak diberikannya informasi yang diminta oleh masyarakat. Sebagai contoh, sejak tahun 2010-2018 kasus sengketa informasi publik yang masuk dan ditangani oleh Komisi Informasi Jawa Timur sebanyak kurang lebih 1400 kasus. Ini membuktikan bahwa budaya birokrasi badan publik di Jawa Timur masih sangat tertutup dan sulit untuk diakses oleh masyarakat, khususnya yang berkaitan dengan permintaan informasi publik. Memang hadirnya UU KIP sebagai sebuah upaya untuk memecahkan problem tersebut. Faktanya, ini menjadi sebuah tantangan besar di tengah-tengah budaya birokrasi yang tertutup dan sudah mengakar sejak zaman orde baru dulu.

Sebenarnya problem di atas bisa saja diatasi jika suatu organisasi birokrasi menjalankan sistem birokrasi sesuai dengan tata aturan yang ada, misalnya sebagai contoh adalah menjalankan amanat UU KIP. Peraturan dan tata tertib dalam sebuah organisasi birokrasi tentunya bertujuan untuk menjamin pelaksanaan wewenang dan fungsi dari birokrasi tersebut bisa berjalan dengan baik. Selain itu peraturan dan tata tertib tersebut juga berkaitan dengan hal apa saja yang tidak boleh dilanggar dan dilakukan oleh aparat-aparat birokrasi. Jika aturan-aturan tersebut ditaati dan dijalankan dengan baik, tentunya juga berimpilkasi pada terciptanya suatu tatanan sistem dan budaya birokrasi yang baik juga. Budaya birokrasi yang baik dibangun berdasarkan sikap dan prilaku sosial dalam lingkungan birokrasi tersebut yang seiring berjalannya proses dapat 
mengkristal membuat suatu tatanan nilai budaya yang baik dalam birokrasi tersebut.

Hadirnya UU KIP adalah respon dari berbagai problem yang muncul dari kelemahan sistem birokrasi dan pelayanan publik di Indonesia, khususnya berkaitan dengan pelayanan akses informasi bagi masyarakat. Selain sebagai instrument hukum untuk menjamin hak asasi manusia dalam memperoleh dan mengakses informasi publik, UU KIP juga sebagai respon dari semangat demokrasi yang diwujudkan dalam cita-cita reformasi. Dalam demokrasi mensyaratkan adanya kebebasan dan keterbukaan dalam memperoleh informasi publik. Keterbukaan atau transparansi dalam perkembangannya menjadi salah satu prinsip atau pilar Negara demokrasi demi terwujudnya control social. Control social tersebut bisa terlaksana jika masyarakat diberikan akses yang terbuka untuk memperoleh informasi berkaitan dengan pelaksanaan kebijakan publik.

Semangat hadirnya UU KIP juga sebagai upaya untuk menciptakan sistem pemerintahan yang bersih dan transparan. Spirit dalam UU KIP tidak hanya sekedar untuk menjamin hak masyarakat mendapatkan akses informasi publik, akan tetapi juga menciptakan sebuah budaya hukum birokrasi pemerintahan yang baik. Melalui implementasi UU KIP diharapkan mampu memberikan sebuah penyadaran terhadap badan publik akan fungsi dan wewenangnya dalam hal pelayanan publik khususnya yang berkaitan dengan pemberian informasi publik bagi masyarakat. Di sisi lain, akan tercipta sebuah tatanan dan budaya birokrasi yang transparan dalam memberikan akses informasi bagi masyarakat, sehingga sebaliknya akses control oleh masyarakat terhadap birokrasi pun semakin mudah. Jika tercapai sebuah kondisi tersebut, maka tindakan kesewanang-wenangan dan penyalahgunaan kekuasaan oleh elit birokrasi yang tidak baik akan bisa diketahui oleh masyarakat, dan tentunya hal tersebut akan meminimalisir prilaku korup dari para elit birokrasi pemerintahan di Indonesia.

\section{Penutup}

Dari uraian ringkas di atas dapat disimpulkan, bahwa implementasi UU KIP untuk menciptakan budaya hukum Badan Publik yang transparan belum 
mampu diwujudkan secara maksimal. Hal tersebut dibuktikan dengan masih banyaknya kasus sengketa bidang informasi publik yang masuk ke Komisi Informasi Jawa Timur pada kurun waktu antara tahun 2010-2018.

Dalam konteks pemerintahan demokrastis, adanya UU KIP sebenarnya adalah wujud dari komitmen untuk menciptakan sistem demokrasi yang ideal, dengan dijaminnya hak masyarakat untuk memperoleh informasi publik sebenarnya juga memberikan sebuah kesempatan bagi masyarakat untuk secara langsung melakukan control terhadap badan publik. Oleh sebab itu, untuk mewujudkan implementasi dari UU KIP yang lebih maksimal khusunya dalam menciptakan budaya hukum transparan pada Badan Publik di Indonesia, maka penguatan fungsi dari UU KIP harus lebih dimaksimalkan, baik oleh Komisi Informasi sendiri dan juga oleh semua Badan Publik pada semua level pemerintahan di Indonesia.

\section{DAFTAR RUJUKAN}

Agus, Dwiyanto. Manajemen Pelayan Publik: Peduli, Inklusif, dan Kolaboratif. Yogyakarta: Universitas Gajah Mada Press, 2015.

Asshiddiqie, Jimly. Hukum Tata Negara dan Pilar-pilar Demokrasi, Serpihan Pemikiran Hukum, Media, dan HAM. Jakarta: Konstitusi Pers, 2005.

Asshiddiqie, Jimly. Pengantar Ilmu Hukum Tata Negara Jilid 2. Jakarta: Sekretariat Jenderal dan Kepaniteraan Mahkamah Konsititusi RI, 2006.

Fadhilla, Putra. New Public Governance. Malang: UB Press, 2012.

Mahdi, Imam. Hukum Tatanegara Indonesia. Yogyakarta: Penerbit Teras, 2011.

Mahfud MD. Politik Hukum di Indonesia. Jakarta: PT. RajaGrafindo Persada, 2012.

Mihardi, R. Muhammad. Kebebasan Informasi Publik Versus Rahasia Negara. Bogor: Penerbit Galia, 2011.

Mulyadi, Muhammad. Partisipasi Masyarakat dalam Pembagunan Masyarakat Desa. Jakarta: Nadi Pustaka, 2009.

Saptomo, Ade. Hukum Dan Kearifan Lokal; Revitalisasi Hukum Adat Nusantara. Jakarta: PT. Gramedia Widiasarana Indonesia, 2010.

Sastro, Dhoho A., dkk. Mengenal Undang-undang Keterbukaan Informasi Publik. Jakarta: LBH Masyarakat dan TIFA, 2010. 
Savas, E.S. "Privatization: The Key to Better Government". New Jersey: Chatam House Publisher, 1987.

Subagyo, Henry. Dkk. Anotasi Undang-Undang Nomor 14 Tahun 2008 Tentang Keterbukaan Informasi Publik. Jakarta: Komisi Informasi Pusat RI, 2009.

Sudibyo, Agus, dkk. Panduan Sederhana Penerapan UU Keterbukaan Informasi Publik. Jakarta: Yayasan Yet.

Tim Penyusun Kontras dan TIFA, Panduan Mengenal Hak atas Informasi Publik dan Pemolisian. Jakarta: Kontras \& TIFA, 2011.

Yurialis. Budaya Birokrasi Pemerintahan, Jurnal Sosial Budaya Vol. 9 No. 1 Januari-Juli 2012

\section{Peraturan perundang-undangan}

Keputusan Menteri Pendayagunaan Aparatur Negara No. 25 Tahun 2004

Keputusan Menteri Pendayagunaan Aparatur Negara No. 58 Tahun 2002

Undang-undang Dasar Republik Indonesia Tahun 1945

Undang-undang No. 25 Tahun 2009 Tentang Pelayanan Publik

Undang-undang No. 14 Tahun 2008 tentang Keterbukaan Informasi Publik, Lembaran Negara Republik Indonesia Tahun 2008 Nomor 61 